\title{
Yield Prediction and Response of Rice-Sorghum Cropping Sequence to Prevailing Weather and Nitrogen Levels
}

\author{
B.V.S. Kiran ${ }^{1 *}$, V.R.K. Murthy ${ }^{1}$, M. Sree Rekha ${ }^{1}$, \\ K. Ashoka Rani ${ }^{2}$ and P.R.K. Prasad ${ }^{3}$ \\ ${ }^{1}$ Department of Agronomy, Agricultural College, Bapatla, ANGRAU, India \\ ${ }^{2}$ Department of Crop Physiology, Agricultural College, Bapatla, ANGRAU, India \\ ${ }^{3}$ Department of SSAC, Agricultural College, Bapatla, ANGRAU, India \\ *Corresponding author
}

\begin{abstract}
Keywords
Weather, Weather health indices, Growth and yield of rice, Yield prediction, Nitrogen

Article Info

Accepted:

24 May 2019

Available Online:

10 June 2019 direction, one of the ways is to use weather and climate as non-monetary input in crop production. Among the crops, rice is a weather sensitive crop. It requires large quantities of water (rainfall) during its growth and development. On the contrary sorghum needs very limited water throughout its life cycle particularly during the vegetative stage in contrast to rice. However, the overall weather that prevails influences the growth and yield of both rice and sorghum. The weather health indices are all weather elements and derived parameters such as GDD, HTU and PTU. Crops are known to modify the weather within their canopies and the soil underneath them. This is further influenced by the cultural and management practices. Nitrogen management is the major practice that affects the yield and quality of both rice and sorghum crops which requires as much as possible at an early and mid tillering stages to maximize panicle numbers and during reproductive stages to produce more number of spikelets per panicle and percentage filled spikelets in rice and during the vegetative and reproductive stages in sorghum. Nitrogen taken up during early growth stages accumulates in the vegetative parts of the plant and is utilized for grain formation. The performance of different genotypes of these crops under varying nitrogen levels are ought to be thoroughly studied under the influence of prevailing weather. Identifying the appropriate rice varieties with proper nitrogen fertilization in response to weather under rice - sorghum sequence were discussed in this review.
\end{abstract}

\section{A B S T R A C T}

The climate determines selection of right crop and its sequence for a particular location, while the prevailing weather conditions dictate the potentiality of that crop and nitrogen use. On an average every $1^{\circ} \mathrm{C}$ rise in temperature could lead to a 20 per cent reduction in crop yields. Therefore, the two big challenges viz., finite cultivable land and rise in temperature have to be overcome by agricultural sector to sustain crop yields. In this

\section{Introduction}

Rice is the most consumed cereal grain in the world, constituting the dietary staple food of more than half of the world population and referred to as "Global grain". The theme "Rice is life" for international year of rice 2004 denoting its overwhelming importance 
as an item of food and commerce. India has largest area under rice in the world i.e., 44.11 million ha and ranks second in production with 108.92 million tonnes with a productivity of $2391 \quad \mathrm{~kg} \quad \mathrm{ha}^{-1}$ (www.Indiastat.com, 2016-17). Agricultural production and productivity of any region is being regulated by the prevailing weather of that area through temperature, rainfall, light intensity, radiation, sunshine duration etc. (Goswami et al., 2006). Weather indices have potential for adoption and use in research on rice based production system to relate crop growth, phenological development and yield. For obtaining high yields, each and every phenophase of rice should optimally use the favourable weather conditions so as to put forth the best performance in obtaining the genetic yield dictated (Sridevi and Chellamuthu, 2015). Crop yield forecasting is an important component for proper planning and policy making in agriculture sector. The District level estimation of crop yield is the basis for planning crop production prospects at State level. Models based on weather parameters can provide reliable forecast of crop yield in advance of harvest (Parbat et al., 2014). Under Forecasting Agricultural output using Space, Agrometeorology and Land Based observations (FASAL) project, the India Meteorological Department (IMD) in collaboration with 46 Agromet Field Units (AMFU) located at different parts of the country develops intra- seasonal operational seasonal forecast at District and State level for 13 major crops of India during kharif and rabi seasons using statistical model (Ghosh et al., 2014)

\section{Weather health indices}

"Weather health" for crop production is defined as "The potential force through which weather elements perform their several and cooperative functions optimally for better crop health to produce potential yields"
(Murthy, 2016), by definition weather health indices are GDD, HTU, PTU etc. These indices have potential for adoption and use in research on cereal crops like rice to relate crop growth, physiological development and yield. The concept of weather indices (Ghosh et al., 2014) assumes that there is a direct and linear relationship between growth of a crop plant and air temperature (GDD) sunshine hours (HTU) and day length (PTU) (Murthy, 2015).

Rice productivity system is subjected to wide aberrations in the economic output and identifying the impact of weather variation at different phenological events of the crop is the predominant area of concern as it may help in understanding their response in terms of final productivity and enhance the functioning of the yield predicting models.

\section{Growing Degree Days (GDD)}

A degree day or a heat unit is the departure from the mean daily temperature above the threshold temperature of the crop. Growing Degree Day (GDD) concept assumes that there is a direct and linear relationship between growth of plants and temperatures. The threshold or base temperature is the temperature below which no growth takes place. This varies with crops, generally higher values for tropical crops and lower values for temperate crops.

\section{Calculation of GDD}

Growing degree days were computed from date of planting to harvesting of the crop to give accumulated growing degree days. This was expressed as ${ }^{0} \mathrm{C}$ day. The GDD was calculated by the equation

$\mathrm{GDD}=\frac{\mathrm{T}_{\max }+\mathrm{T}_{\min }}{2}$ 
Where, $\mathrm{T}_{\max }=$ Maximum temperature, $\mathrm{T}_{\min }=$ Minimum temperature, $\mathrm{T} b=$ Base temperature

\section{Helio Thermal Units (HTU)}

Helio thermal unit (HTU) was calculated by multiplying GDD with actual bright sunshine hours which was measured daily with the help of sunshine recorder.

\section{Calculation of HTU}

The HTU was calculated by the equation and expressed as ${ }^{0} \mathrm{C}$ day hour.

HTU $=(G D D) X($ Bright sunshine hours $)$

\section{Photo Thermal Units (PTU)}

GDD concept was improved by applying day length factor and used photo thermal unit (PTU) concept in climatic analogue studies. This is calculated by multiplying GDD with maximum possible bright sunshine hours. This is expressed as ${ }^{0} \mathrm{C}$ day hour.

\section{Calculation of PTU}

The PTU was calculated by the equation and expressed as ${ }^{0} \mathrm{C}$ day hour.

$\mathrm{PTU}=(\mathrm{GDD}) \mathrm{X}$ (Day length)

GDD at panicle initiation, flowering and physiological maturity were highly significant and positively correlated with grain yield and total biomass. Cumulative PTU for all the three stages were directly and significantly associated with grain yield. By combining both results it can be inferred that during short photoperiod crop season, cultivars with longer crop duration may be the suitable choices for optimum yield. Cumulative HTU at all three stages was highly associated with the grain yield and describes the effect of sunny day on the partitioning of the total biomass into grain yield (Shamim et al., 2013).

\section{Yield prediction in rice}

Rice crop yield data and weather data can be used to develop yield forecasting model. The weather data used is standard meteorological weeks (SMW) of each year i.e., the period from transplanting to harvest of rice. However, the average value for entire crop season was taken in yield prediction model (Murthy, 2016). The variables can be used were weekly rainfall $(\mathrm{mm})$; maximum, minimum and mean temperature; morning and evening relative humidity (\%); sunshine hours (hr); derived parameters viz., growing degree days; helio thermal units and photo thermal units. For selecting the best regression equation among number of independent variables, stepwise regression procedure can be adopted. Appropriate computer software can be used for analysis of data with probability level. A regression model can be derived considering the entered variables obtained from individual stepwise regression analysis to predict the yield of rice for the subsequent years. The multiple linear stepwise regression analysis can be developed on the basis of examination of coefficients of determination $\left(\mathrm{R}^{2}\right)$, standard error (SE) of estimates values resulted from different weather health indices. Two statistical tests, percent Mean Bias Error (MBE) and percent Root Mean Square Error (RMSE) can be used to the degree of accuracy of each considered correlation to fit the measured data. MBE provide information on the long term performance and RMSE short term performance of the model. The best weather health indices were selected to develop agro meteorological yield model based on the methodology given by Zaman et al., (1982).

The basic Linear regression model obtained from a data series of 29 years (1970 to 1998) 
is shown in Table 1. The linear model successfully accounted for 63 per cent of total variation in rice yield with a multiple correlation coefficient (MCC) of 0.79. The analysis of variance proved that the model were highly significant at $1 \%$ level when it's computed F-value of 6.23 (linear regression) which was greater than the tabulated value of 4.17. The performance of different basic models within test period revealed that the deviation in predicting yield was 64 per cent for linear model. (Gill, et al., 2014)

Table.1 Basic linear regression model to forecast rice yields

\begin{tabular}{|l|l|l|l|l|l|}
\hline Model & Multiple regression equation & $\begin{array}{l}\text { Percent } \\
\text { variation }\end{array}$ & MCC & $\begin{array}{l}\text { Computed } \\
\text { F value }\end{array}$ & $\begin{array}{l}\text { Tabled } \\
\text { F value }\end{array}$ \\
\hline $\begin{array}{l}\text { Basic linear } \\
\text { regression }\end{array}$ & $\begin{array}{l}\mathrm{Y}_{\mathrm{el}}=-955-24.4 \mathrm{X}_{1}+81.4 \mathrm{X}_{2}-1.2 \mathrm{X}_{3}+ \\
36.9 \mathrm{X}_{4}-52.9 \mathrm{X}_{5}+38.7 \mathrm{X}_{6}\end{array}$ & 0.63 & 0.79 & 6.23 & 4.17 \\
\hline
\end{tabular}

$\mathrm{Y}_{\mathrm{el}}=$ Estimated Yield by linear function model $\left(\mathrm{kg} \mathrm{ha}^{-1}\right)$

\section{Yield prediction in Sorghum}

The basic knowledge, methodologies and tools required for the jowar crop can be taken from DSSAT, CROPGROW and EPSIM. The variations in jowar yield that can be attributed to weather vis-a-vis climate change have to be tested using the best possible statistical models as well (Zaman et al., 1982). The yield and production of the jowar crop and weather variables such as minimum, maximum and mean temperature, the derived weather indices such as GDD, HTU, PTU and rainfall have to be used. A combination of biometrical observations and weather variables of crop grown can be used to test the validity of the both simulation and regression models.

\section{Nitrogen fertility}

Nitrogen fertility is becoming increasingly important for gaining economic and environmental validity of agro-ecosystem and exploiting rice varieties to nitrogen demand for a possible alternative in reducing the cost and dependence upon nitrogen fertilizer. Nitrogen fertilization has a vital role in determining the percentage nitrogen in the rice grains and nitrogen uptake by the rice plants. Nitrogen management is the major practice that affects the yield and quality of rice crop which requires as much as possible at an early and mid tillering stages to maximize panicle numbers and during reproductive stages to produce more number of spikelets per panicle and percentage filled spikelets (Lampayan et al., 2010). This might be due to that the nitrogen is absorbed during differentiation mainly the leaves and stems contain a large portion of the nitrogen taken up by the rice plants in the present study. These findings are in line with Meena et al., (2017) who reported that increasing nitrogen levels up to $150 \mathrm{Kg} \mathrm{Nha}{ }^{-1}$ significantly increased grain yield $\left(4340 \mathrm{~kg} \mathrm{ha}^{-1}\right)$ and biological yield $\left(1008 \mathrm{~kg} \mathrm{ha}^{-1}\right)$. Rice growth characteristics namely, tillers $\mathrm{m}^{-2}$, leaf area index, drymatter content, grain yield and its components (i.e., number of panicles $\mathrm{m}^{-2}$, number of grains/panicle, percentage filled grain and 1,000 grain weight) were significantly increased when rice was fertilized with $144 \mathrm{~kg} \mathrm{~N} \mathrm{ha}{ }^{-1}$ (Saha et al., 2017).

The response of rice varieties to over and above recommended dose of nitrogen on dry matter production, yield and nitrogen uptake and were significantly influenced by varieties and nitrogen levels. The variety NLR 28523 showed significantly higher drymatter 
production (1164.1 $\mathrm{kgha}^{-1}$ ) at 90 DAS, yield $\left(5680 \mathrm{~kg} \mathrm{ha}^{-1}\right)$ and nutrient uptake $(114.6 \mathrm{~kg}$ $\mathrm{ha}^{-1}$ ) over other varieties viz., NLR 33892, BPT 5204 and NLR 1061. Application of 240 $\mathrm{kg} \mathrm{N}^{-1}$ showed higher drymatter production $\left(1167.4 \mathrm{~kg} \mathrm{ha}^{-1}\right)$ at $90 \mathrm{DAS}$, yield $(5650 \mathrm{~kg}$ $\left.\mathrm{ha}^{-1}\right)$ and nitrogen uptake $\left(124.9 \mathrm{~kg} \mathrm{ha}^{-1}\right)$ than other nitrogen levels viz., 120, 150, 180 and $210 \mathrm{~kg} \mathrm{~N} \mathrm{ha}^{-1}$ (Rao, et al., 2013).

The rice fallows offer good scope for area expansion of jowar crop and crop intensification. Their productive utilization can overcome many social and economic problems like, unemployment, labour migration and low income. Production and productivity of rice in terms of its yield, grain weight and number of grains per unit area vary in response to agro-meteorological parameters that accelerate the processes of plant growth and development. Moreover, meteorological parameters vary yearly and intra and inter-seasonal variations play a pivotal role in determining the final crop yield. Yield prediction of both the crops is also very much possible using weather parameters and their indices. Minimum temperature, afternoon relative humidity, growing degrees and helio thermal units are the significant weather health indices which can comfortably be incorporated in agro meteorological models for yield prediction of rice which in turn helps for planning purposes.

The performance of the models was found to be good. The models provided reliable forecasts of crop yield well in advance of harvest and timely forewarning of pest population/disease severity could be given. Application of appropriate levels of nitrogenous fertilizers is one of the important factors to increase nitrogen use efficiency by rice cultivars. Improve of nitrogen use efficiency can be achieved through optimum nitrogen application rates.

\section{References}

Ghosh, K, Balasubramanian, R, Bandopadhyay, S, Chattopadhyay, N, Singh, KK and Rathore, LS. 2014. Development of crop yield forecast models under FASAL- A case study of kharif rice in West Bengal. Journal of Agrometeorology 16(1): 1-8.

Gill, K.K., Kiran, R. and Paul, S. 2014. Meteorological model for rice yield forecasting in Ludhiana region. Indian Journal of Ecology, 41(2): 257-261.

Goswami, B, Mahi, GS and Saikia, US. 2006. Effect of few important climatic factors on phenology, growth and yield of rice and wheat-A review. Agricultural Reviews, 27(3): 223-228.

Lampayan, RM, Bouman, BAM, Dios, JLD, Espirity, AJ, Soriano, JB, Lactaoen, AT, Faronilo, JE and Thant, KM. 2010. Yield of aerobic rice in rainfed lowlands of the Philippines as affected by nitrogen management and row spacing. Field Crops Res. 116:165-174.

Meena, R.P., Prasad, S.K., Layek, A., Singh, M.K and Hingonia, K. 2017. Nitrogen and zinc scheduling for productivity and profitability in direct-seeded rice (Oryza sativa).Indian Journal of Agronomy, 62(4): 525-527.

Murthy, VRK. 2015. Climate change-weather health indices as tools and services in agriculture. Andhra Agricultural Journal, 62(4): 737-745.

Murthy, VRK. 2016. Principles and practices of agricultural disaster management. B.S. Publications, Koti, Hyderabad, Telangana, Pp: 111-127.

Parbat S. K., Giri R.K., Singh K.K and Baxla A.K. 2014. Rice and Jute yield forecast over Bihar region. International Research Journal of Engineeringand Technology, 3(2):1636-1647.

Rao, VP, Subbaiah, G and Sekhar, KC. 2013. Response of rice varieties to high level 
nitrogen on drymatter production, yield and nitrogen uptake of rice. International J. Applied Bio. And Pharmaceutical Technology, 4(4): 216218.

Saha, B., Panda, P., Patra, P.S., Panda, R., Kundu, A., Roy, A.S and Mahato, N. 2017. Effect of different levels of nitrogen on growth and yield of rice (Oryza sativa L.) cultivars under teraiagro climatic situation. International Journal of Current Microbiology and Applied Science, 6(7): 2408-2418.

Shamim, M, Devendra, S, Gangwar, KK and Vipin, K. 2013. Agrometeorological indices in relation to phenology, biomass accumulation and yield of rice genotypes under Western Plain zone of Uttar Pradesh. J. Agrometeorology, 15(special issue-II): 50-57.

Sridevi, V and Chellamuthu, V., 2015. Impact of weather on rice-A review. International Journal of Applied Research, 1(9), pp.825-831.

www.Indiastat.com, 2016-17, Ministry of Agriculture, Government of India.

Zaman, SMH, Kamal, R, and Mcintosh, H. 1982.Simple lessons from Biometry. Bangladesh Rice Research Institute, Decca, Bangladesh.

\section{How to cite this article:}

Kiran, B.V.S., V.R.K. Murthy, M. Sree Rekha, K. Ashoka Rani and Prasad, P.R.K. 2019. Yield Prediction and Response of Rice-Sorghum Cropping Sequence to Prevailing Weather and Nitrogen Levels. Int.J.Curr.Microbiol.App.Sci. 8(06): 3154-3159.

doi: https://doi.org/10.20546/ijcmas.2019.806.377 